\title{
Medicinska etika u palijativnoj skrbi
}

\author{
Morana Brkljačić*
}

\begin{abstract}
Sažetak
Palijativna skrb, odnosno medicina sveobuhvatna je aktivna skrb o bolesnicima s uznapredovalom ili neizlječivom bolesti i članovima njihovih obitelji koju pružaju kompetentni multidisciplinarni timovi, s ciljem poboljšanja kvalitete života a prema potrebama i zahtjevima pacijenta $i$ obitelji. "Onomu koji odlazi iz života treba posvetiti jednaku pažnju zajednice kao i onomu malenomu ljudskomu biću koje tek ulazi u život”, rekla je jednom prilikom utemeljiteljica palijativne medicine u Hrvatskoj Anica Jušić. Moramo pokušati promijeniti mentalitet naše sredine te ostvariti obrazac u kojem će bolesnik biti u središtu zbivanja. U posljednjih dvadesetak godina palijativna medicina zaokuplja pozornost medicinske struke i poprima rastuću važnost u svijetu prvenstveno jer utjelovljuje koncept skrbi, a ne samo liječenja, razvijajući time opću svijest o važnosti skrbi, osobito kada liječenje više nije moguće. Palijativna medicina kao grana medicine koja proučava i skrbi za bolesnika s progresivnom, uznapredovalom bolesti ograničene prognoze brine se za optimalnu kvalitetu preostaloga života i prihvaćanju umiranja kao prirodnoga događaja, koji zdravstveni djelatnici interdisciplinarno sa psiholozima, socijalnim radnicima, ljekarnicima i duhovnicima trebaju potpomoći usmjeravanjem, preveniranjem komplikacija, ublažavanjem boli i patnje, pomaganjem da umiranje postane manje bolan događaj dostojan svih koji $u$ njemu sudjeluju. Sukladno brojnim kodeksima medicinske etike i deontologije, jedno od najvažnijih obilježja medicinskoga poziva pomoć je i briga (skrb) za pacijenta, poglavito onoga teško bolesnoga i umirućega.
\end{abstract}

Ključne riječi: palijativna medicina, palijativna skrb, medicina, medicinska etika

\section{Uvod}

Kada se smrt prihvati kao normalan proces, palijativna skrb postaje najprikladniji pristup pacijentu. Takav pristup ne znači da se više ništa ne može učiniti, dapače, znači primjenu suosjećajne ekspertize radi ublažavanja ili palijacije tje-

* Doc. dr. sc. Morana Brkljačić, dr. med. Medicinski fakultet Sveučilišta u Zagrebu i Hrvatsko katoličko sveučilište. Adresa: Šalata 3, 10000 Zagreb, Hrvatska i Ilica 242, 10000 Zagreb, Hrvatska. E-adresa:morana_brkljacic@yahoo.co.uk 
lesne, emocionalne, duhovne ili društvene boli. Agresivno kurativno medicinsko liječenje često nije odgovarajuće, a posljedice su produljena patnja, smanjenje kvalitete života i zanemarivanje pacijentovih prioriteta. Pravo je svakoga ljudskoga bića da se bez boli i uz što manju duševnu patnju suočava s uznapredovalom ili terminalnom bolesti, a to mu omogućavaju postupci i stavovi moderne palijativne skrbi, odnosno medicine. Prema definiciji Svjetske zdravstvene organizacije palijativna je skrb pristup koji poboljšava kvalitetu života bolesnika i njihovih obitelji, suočavajući se s problemima vezanim uz bolest koja prijeti životu. Čini to putem sprečavanja i olakšanja trpljenja, pomoću rane identifikacije i besprijekorne prosudbe i liječenja boli i drugih problema, fizičkih, psihosocijalnih i duhovnih $^{1}$ (World Health Organisation, 2003). Naglasak je na interdisciplinarnom liječenju bolesnika i članova obitelji od spoznaje o dijagnozi neizlječive bolesti do razdoblja žalovanja nakon smrti pojedinca. Imperativ je svih vlada razvoj plana zdravstvenih aktivnosti koje uključuju i palijativno liječenje.

Palijativna skrb osnovno je ljudsko pravo na zdravstvenu zaštitu, pravo koje naglašava još Kanadska deklaracija iz 1992. i 2000., Cape Town deklaracija iz 2003., Preporuke ministara Vijeća Europe iz 2003., Europska škola onkologije iz 2004., izjava pape Benedikta XVI iz 2007., Barcelonska deklaracija o palijativnoj skrbi iz 2005., Korejska deklaracija iz 2005. oblikovana na Drugom globalnom sastanku Društava hospicija i palijativne skrb u Seulu te Venecijanska deklaracija s ciljem podrške razvoja istraživanja na području palijativne skrbi u zemljama u razvoju iz 2006. godine.

U dodatku Preporuke Povjerenstva ministara Vijeća Europe državama članicama o organizaciji palijativne skrbi, naglašava se, između ostaloga, da se politika palijativne skrbi treba zasnivati na ljudskim i bolesničkim pravima, ljudskom dostojanstvu, socijalnoj povezanosti, demokraciji, jednakosti, solidarnosti, jednakim mogućnostima s obzirom na spol, sudjelovanju i slobodi izbora. Kao i u svim područjima medicinske skrbi, zdravstveni djelatnici uključeni u palijativnu skrb moraju u potpunosti poštovati prava bolesnika, biti u skladu s profesionalnim obvezama i standardima i u tom kontekstu raditi u interesu bolesnika (Recommendation Rec., 2003). Organizacija palijativne medicine potrebna je na svim razinama zdravstvene zaštite (kućne posjete palijativnoga tima, bolnički palijativni timovi, ustanove za palijativnu medicinu, klinike, odjeli, hospiciji i dr.), a više od 120 zemalja u svijetu ima različite modele organizirane palijativne medicine. U Hrvatskoj još ne postoji nijedna ustanova za palijativnu medicinu, iako je to područje regulirano Zakonom o zdravstvenoj zaštiti još 2003. godine. ${ }^{2}$ Iako

1 Citati izvorno na stranim jezicima prijevod su autora rada.

Palliative care is an approach that improves the quality of life of patients and their families facing the problem associated with life-threatening illness, through the prevention and relief of suffering by means of early identification and impeccable assessment and treatment of pain and other problems, physical, psychosocial and spiritual.

2 Hrvatski sabor na temelju članka 88 Ustava Republike Hrvatske donio je odluku o proglašenju zakona o zdravstvenoj zaštiti gdje je navedeno u odjeljku Razine zdravstvene djelatnosti, članak 25 da palijativna skrb predstavlja zdravstvenu djelatnost na primarnoj razini (NN 121/2003). 
ne postoji ustanova, ipak postoje sustavi organizacije palijativne skrbi kao što su mobilni timovi palijativne skrbi na primarnoj razini u Rijeci, Puli, Zagrebu i Čakovcu, a od strane Ministarstva zdravstva i palijativni odjeli u Novom Marofu, Kninu, Varaždinu, Dubrovniku i Zagrebu, Odjel palijativne skrbi i dugotrajnoga liječenja u psihijatarskoj bolnici Sveti Rafael na Strmcu. Svime navedenim palijativna medicina postaje dio zdravstvenoga sustava i na primarnoj i na sekundarnoj razini zdravstvene skrbi u Republici Hrvatskoj.

Od pamtivijeka se smatra da je medicinska profesija vještina koja mora počivati na dva kamena temeljca: jedan je visoka stručnost i vladanje medicinskom znanošću, a drugi se ogleda u načelu humanosti i visoke etičnosti koja krasi zdravstvenu struku (Zurak, 2007, 204).

Sukladno brojnim kodeksima medicinske etike i deontologije, jedno od najvažnijih obilježja medicinskoga poziva pomoć je i briga (skrb) za pacijenta, poglavito onoga teško bolesnoga i umirućega. Doprinos i olakšavajuće okolnosti takvoga oblika pomoći dakako je napredak kako medicinskih, tako i farmaceutskih znanstvenih dostignuća. Do sredine 20. stoljeća navedene su znanosti bile relativno ograničene u suzbijanju boli i kontroli simptoma. Napredak u ljekovitoj terapiji pedesetih godina 20. stoljeća, u kombinaciji s većim razumijevanjem psihosocijalnih i duhovnih potreba umirućih bolesnika, utrli su put razvitku palijativne, odnosno hospicijske skrbi (Higginson, 2005).

\section{Palijativna skrb}

Utemeljen i dokazan model skrbi za bolesnike u završnoj fazi bolesti palijativna je skrb. Započinje kada su iscrpljene klasične (kurativne) metode liječenja ili kad su znaci širenja maligne bolesti dostignuli takav stupanj da ih bolesnik teško podnosi. Primarni je cilj kurativne medicine izlječenje, a smrt zadnji neuspjeh. U palijativnoj medicini to je olakšanje patnje, a smrt koja se desi nakon što je bolesniku olakšana patnja — uspjeh.

Palijativna medicina mnogo je šira i dublja od puste simptomatologije. Termin implicira holistički pristup bolesniku, što podrazumijeva ne samo fizičku dimenziju, nego i psihološku, društvenu i duhovnu zaokupljenost.

Najveći dio palijativne skrbi odvija se kod kuće bolesnika. Čak i ako bolesnik umre u ustanovi (bolnica, dom i sl.), obično treba dug period palijativne skrbi koju treba provesti u njegovu domu. Upravo je stoga od izuzetne važnosti da bolesnici imaju mogućnost pristupa skrbi u vrijeme i u jedinici koja je u skladu s njihovim kliničkim potrebama i osobnim zahtjevima i željama. Stoga je odgovornost svih profesionalaca da budu upoznati s osnovnim načelima palijativne skrbi. Kako bi se postignuo taj cilj, obveza je Ministarstva zdravstva i socijalne skrbi uključiti palijativnu skrb kao dio osnovnoga kurikula za medicinare i ostale zdravstvene djelatnike, odnosno profesionalce.

Pretpostavlja se kako izraz za život opasna ili degenerativna bolest obuhvaća široku populaciju pacijenata različite životne dobi te različitih dijagnoza, koje štetno utječu na bolesnikove svakodnevne funkcije ili pak smanjuju njegov oče- 
kivani životni vijek. Palijativna skrb namijenjena je djeci i punoljetnim osobama koje pate od prirođenih bolesti, osobama bilo koje dobi koje pate od akutnih, ozbiljnih i po život opasnih bolesti, osobama koje pate od progresivnih kroničnih stanja, osobama koje pate od kroničnih i za život ograničavajućih povreda te ozbiljno i terminalno oboljelim pacijentima (Doyle et al., 1998).

\subsection{Organizacijski oblici palijativne skrbi}

Način kojim nastojimo utvrditi i odgovoriti na jedinstvene i individualne potrebe umirućih i njihovih obitelji dok se bore s progresivnim gubitkom, pokazatelj je naše zrelosti kao društva. Gdje god je moguće, moramo prevenirati bolest. Ako se bolest razvije, moramo je nastojati iskorijeniti ili barem odgoditi njezinu progresiju. Paralelno s tim naporima svim bolesnicima moramo pružiti optimalnu razinu kontrole boli i drugih simptoma uz psihološku, emocionalnu i duhovnu potporu. Organizacijski oblici palijativne skrbi koji danas djeluju u Europi i svijetu su kućna palijativna skrb, dnevni hospicijski boravci, ambulante, odnosno savjetovališta za palijativnu skrb, ambulante za bol, palijativni odjeli u bolnicama, hospiciji i službe žalovanja (National Consensus Project for Quality Palliative Care, 2004).

\subsection{Hospicij}

Hospicij je moderna zdravstvena ustanova s nizom sustava pružanja pomoći bolesnicima u terminalnoj fazi bolesti. Koordinirani program palijativne i potpomognute (suportivne) skrbi, koji nudi hospicij, reagira na potrebe umirućih pacijenata pribavljajući alternativu agresivnoj, kurativno usmjerenoj skrbi. Fokus je plana skrbi na kvaliteti preostaloga života, olakšanju bolnih simptoma i podršci u žalovanju. Hospicijska skrb ne pravda niti sudjeluje bilo u kojem postupku kojemu je cilj ubrzati ili produljiti pacijentovu smrt. Naprotiv, svi aspekti skrbi usmjereni su na stvaranje ugode, štovanje života i optimizaciju pacijentove kontrole i autonomije (Smith, 2000). Pacijent i njegova obitelj trebaju biti uključeni u donošenje odluka vezanih uz tretman i skrb o pacijentu na način da im se osigura dovoljno informacija o bolesti, tretmanu, pristupu i mogućnostima kako bi se mogla realizirati informirana suglasnost, doktrina medicinske etike. Hrvatska danas ima jedan hospicij naziva: Marija Krucifiska Kozulić u Rijeci (Brkljačić, 2009, 473-480).

\subsection{Interdisciplinarni tim palijativne skrbi}

Interdisciplinarni tim temeljan je za potpunu hospicijsku, odnosno palijativnu skrb. Taj tim čine: liječnik educiran iz područja palijativne medicine, kao i medicinska sestra, fizijatar, socijalni radnik, duhovnik, ljekarnik, psiholog, nutricionist.

Zbog čestih komplikacija i problema s kojima su suočeni bolesnici s uznapredovalom bolešću i njihove obitelji interdisciplinarni tim treba pružiti kako opću tako i specijaliziranu skrb. Treba biti spreman pružiti fizičku, psihološku, soci- 
jalnu i duhovnu potporu pomoću metoda koje proizlaze iz interdisciplinarnoga, kolaborativnoga timskoga pristupa.

Interdisciplinarnost i multidisciplinarnost tima palijativne, odnosno hospicijske skrbi već u svojem nazivu ide u prilog holističkomu pristupu pacijentu. Jedan je od primarnih ciljeva palijativne skrbi, odnosno medicine stvoriti osjećaj teško bolesnomu pacijentu da nije sam, dakle osjećaj nenapuštenosti pri odlasku iz ovozemaljskoga života te zadovoljenje njegovih duhovnih potreba, kao i poštivanje njegove autonomnosti i želje. Upravo te ciljeve interdisciplinarni tim prepoznaje, potpomaže i poštuje kroz svoje tretmane, prevencije te promocijom temeljnih strategija skrbi. Interdisciplinarni tim u suradnji s pacijentom, njegovom obitelji, odnosno njegovateljima razvija i održava individualiziran, siguran i koordiniran plan palijativne skrbi (Cummings, 1998).

\section{Medicinska etika}

\subsection{Medicinska etika u palijativnoj medicini i njezinoj skrbi}

Etika je filozofska disciplina koja istražuje problematiku morala. Riječ etika dolazi od grčkih riječi ethos, što običaj, i ethicos, što znači moralan. Etika je znanost o moralu ili moralnom fenomenu (lat. mos, moris, običaj narav, navika, ćud; hrvatski ćudoređe, red u ćudi). Moral ili ćudoređe možemo definirati kao društveno pozitivnu praksu odnosa čovjeka s ljudima, društvom i samim sobom.

Unutar kompleksa medicinske etike razlikuju se humana medicinska etika i veterinarska etika. Humana se pak može podijeliti na stomatološku i liječničku te ljekarničku u užem smislu riječi. Deontologija je širi pojam od medicinske etike. Medicinska deontologija bavi se proučavanjem i određivanjem prava i dužnosti liječnika (Zurak, 2007, 3).

Medicinska znanost udružena s napretkom tehnologije u mnogom je doprinijela usavršavanju održavanja ljudskoga zdravlja, a time neizbježno i produljenje dužine ljudskoga života, no istovremeno tim je činom razvila neke nove probleme vezane uz problematiku smrti i umiranja. Uz tako rastuću primjenu raznih medicinsko-tehnoloških pomagala s ciljem produženja dužine života, medicina je nužno morala razviti i razvila je skup novih načela nužnih u rješavanju složenih etičkih problema (Brkljačić Žagrović, 2010).

Medicinska etika palijativne skrbi od posebnoga je interesa zato što u žarište postavlja aspekte skrbi usmjerene na pacijenta i kritičko donošenje odluka. Vrsta odluka koje se donose u okruženju terminalno oboljeloga razlikuju se po prirodi od odluka u akutnoj (kurativnoj) medicini, gdje se primjerice razmatraju radikalne intervencije. Neke odluke intrinzično zahtijevaju vrstu vrijednosne prosudbe, kada se klinički aspekti njege moraju pažljivo vagati u odnosu na pacijentove izražene ili doživljene želje ili uvjerenja.

Logička načela za kliničko donošenje odluka uključuju podjednako medicinske i (bio)etičke kriterije. Etika kritička prosudba u donošenju odluka često se ne može odvojiti od kliničkih okolnosti koje okružuju određeni slučaj, jednako 
kao što se medicinsko donošenje odluka ne može sagledavati neovisno o svojim etičkim implikacijama (Pellegrino et al., 1990).

Palijativna je medicina područje gdje postoji obilje etičkih tema. Većina je slična onima koje se pojavljuju u drugim područjima zdravstvene skrbi. Neke se teme, poput onih povezanih s krajem života, očito jače ističu. Razmišljanja o etičkim načelima uključenima u palijativnu skrb zasnivaju se na prepoznavanju činjenice da neizlječivi i/ili terminalni bolesnik nije biološki ostatak za koji se više ništa ne može učiniti, biće koje treba anesteziju, čiji život ne treba nepotrebno produživati, nego osoba koja je sposobna do samoga svršetka.

Kao i u svim drugim područjima medicinske skrbi, slijedeći četiri etička načela — od kojih je dva prije gotovo 2500 godina postavio Hipokrat "činiti dobro, ne činiti zlo", a 1979. nadopunili Beauchamp i Childress "poštovati autonomiju, poštovati pravdu« - liječnici koji se bave palijativnom medicinom i drugi koji skrbe trebaju poštovati bolesnikovu autonomiju, prihvaćati prioritete i ciljeve skrbi i bolesnika i onih o kojima se skrbi, ne skrivati podatak koji bolesnik želi znati te poštivati bolesnikovu želju da ga se ne liječi (Beauchamp i Childress, 1994, 23-24).

Oni koji skrbe moraju pažljivo odvagati koristi i opterećenja liječenjem (eng. beneficence) i procijeniti rizike spram koristi svake kliničke odluke (eng. nonmaleficence) kako bi izbjegli beskorisno liječenje koje ne služi ciljevima prevencije, liječenja, skrbi, rehabilitacije i oslobađanja od boli. Potrebno je izbjegavati i intervencije koje su, iako mogu postići parcijalne rezultate, štetne za bolesnikovu opću dobrobit. Bolesnici s uznapredovalom bolešću kao i umirući imaju, u biti, ista prava kao i drugi pacijenti, odnosno građani. Imaju pravo na medicinsku skrb i osobnu potporu (primjerice da uz krevet bude bliski srodnik), pravo da budu informirani (informirana suglasnost, eng. informed consent), ali i pravo da odbiju informaciju i/ili dijagnostički postupak i/ili liječenje (Faden, 1999, 11). Odbijanje liječenja treba osigurati osobito ako primjereno medicinsko liječenje neće smrt učiniti boljom. Odbijanje liječenja ne smije utjecati na kvalitetu palijativne skrbi. Vrlo je važno da bolesnici u palijativnoj skrbi imaju pravo na maksimalno dostižno ljudsko dostojanstvo, na najbolje moguće oslobađanje od boli i redukcije patnje.

Postoji dinamika odnosa između liječnika palijativne skrbi i interdisciplinarnoga tima, kao i dinamika odnosa s pacijentom i pacijentovom obitelji, a oba traže posebne vještine, koje ne moraju biti strogo kliničke. Kliničari, poglavito liječnici, članovi interdisciplinarnoga tima palijativne, odnosno hospicijske skrbi, moraju biti sposobni baviti se moralnim konfliktima koji nastaju u kontekstu moderne kliničke prakse. U slučaju stručnjaka za palijativnu skrb, tj. članova interdisciplinarnoga tima palijativne skrbi etika ima važnu ulogu u kontekstu donošenja odluka, planiranja i pružanja njege.

\subsection{Temeljna etička načela}

Temeljne etičke vrijednosti i u palijativnoj medicini i u njezinoj skrbi ostvarene su kroz četiri temeljna etička načela (Pellegrino et al., 1990). 
Dobročinstvo i neškodljivost zahtijevaju od osobe koja skrbi za pacijenta obvezu maksimalne dobrobiti i minimalne štete za pacijenta. Možda se, naizgled, ispunjenje navedenih načela čini vrlo jednostavnim zadatkom, međutim, ono što je za jednoga pacijenta vrhunac dobrobiti i neškodljivosti, za drugoga pacijenta ne treba biti ili se pak prema tom pacijentu ne ostvaruje maksimalno dobročinstvo i minimum škodljivosti, za njega. Golema raznolikost kultura, religija, vjerovanja i načina života ukazuju na potrebu onoga koji skrbi za pacijenta da se ne ustručava pitati pacijenta što je za njega najbolje te koji je najbolji način da se to i učini. Upravo tim načinom komunikacije osiguravamo, kao skrbnici, maksimum činjenja dobroga, tj. ne činjenja škodljivoga.

Autonomnost predstavlja načelo temeljeno na samosvjesnosti i samoodređenju pacijenta te na njegovu pravu na donošenje odluke. Koncept čestitosti (integracije) i informirane suglasnosti ključ su svih rasprava o autonomiji pacijenta. Također, moramo kao skrbnici, članovi interdisciplinarnoga tima (bilo liječnici, medicinske sestre ili pak neko drugo zdravstveno osoblje) biti spremni i na "informiranu nesuglasnost - odbijanje" kao jednu od mogućnosti pacijentova odabira i time dokazati svoju etičku zrelost u poštivanju pacijentove autonomnosti odlučivanja.

Pravednost predstavlja načelo koje je glavni izlaz u rješavanju svih diskusija čija je srž problema u različitosti. Različitost (nejednakost), osobito mišljenja i stavova, najčešći je problem nevjerovanja pacijenta u odluke i medicinskoga profesionala i interdisciplinarnoga tima. Treba spomenuti istinoljubivost i povjerenje kao izvedena etička načela, čija je uloga, upravo u palijativnoj skrbi, temelj izgradnje kvalitetnoga odnosa između pacijenta i članova interdisciplinarnoga tima, a svoje uporište nalazi u govorenju istine, čuvanju tajne i ispunjenju obećanja.

Etika palijativne medicine koja se odnosi na pažnju i usmjerenost prema terminalnim pacijentima određena je kroz pet načela: načelo istinitosti, načelo terapijske razmjernosti, načelo dvostrukoga učinka, načelo prevencije, načelo nenapuštanja i tretman boli (Pessini, 2001).

\subsection{Izvedena etička načela}

Načelo istinitosti temelji se na istinitosti kao temelju povjerenja u interpersonalnim odnosima. Reći istinu pacijentu i njegovoj obitelji predstavlja pogodnost za oboje (načelo dobročinstva) jer omogućuje aktivno sudjelovanje pacijenta $u$ procesu donošenja odluka (autonomija). U medicinskoj praksi česte su situacije kada reći istinu nije jednostavna liječnička zadaća, primjerice priopćiti lošu vijest kao što je dijagnoza progresivnih i neizlječivih bolesti ili pak prognozu o skoroj i neizbježnoj smrti. Nerijetko se u takvim okolnostima javlja lažni paternalistički stav koji pacijentu prikriva istinu. Tim se činom ulazi u začaran krug nazvan "zavjera šutnje", koji, osim što pacijentu nameće nove oblike patnje, može biti uzrok teške nepravde.

Načelo terapijske razmjernosti zasniva se na moralnoj obvezi da se pravedno provedu sve terapijske mjere koje su u odnosu razmjernosti između primjenji- 
vih sredstava i predvidivoga rezultata. Postoje elementi o kojima se nužno vodi računa, primjerice korisnost ili uzaludnost mjere, alternative čina, rizici i pogodnosti terapije, kao i njezina cijena. Liječnici imaju dvostruku odgovornost, a to je sačuvati život i ublažiti patnju. Bez sumnje, ublažavanje patnji na kraju života dobiva svakodnevno sve veću pozornost. Dio je medicinske vještine i odluka o održavanju života kada je ono suštinski uzaludno. Liječnik nije dužan održavati život “pod svaku cijenu”. Prioriteti pažnje mijenjaju se kada pacijent očito umire i ne postoji obveza primjene tretmana koji umjesto života jednostavno produžuju život.

Načelo nenapuštanja odnosi se na etičku, odnosno moralnu obvezu liječnika da ne napusti pacijenta u slučaju njegove (pacijentove) odluke odbijanja terapije ordinirane od strane njegova liječnika, čak i kada bi liječnik smatrao da je odbijanje neprikladno. Nalazeći se uz svojega pacijenta i uspostavljajući jedan vid empatičke komunikacije, liječnik će možda postići da pacijent ponovo razmisli o određenim odlukama vezanim uz svoje zdravlje i terapiju.

\subsection{Dokumenti medicinske etike u palijativnoj medicini}

U provedbi palijativne medicine, odnosno skrbi, a u vezi s poštivanjem odluke pacijenta, danas postoji niz dokumenata, od kojih su u kontekstu palijativne medicine ipak dva najbitnija. S njima interdisciplinarni tim palijativne, odnosno hospicijske skrbi, prvenstveno zdravstveni dio tima kao i ravnatelj hospicija, moraju biti upoznati.

To su obaviješteni pristanak (informirana suglasnost) (eng. informed consent) te biološki testament (eng. living will, biocard) ili karta samoopredjeljenja.

Informirana suglasnost izjava je pacijenta koja opunomoćuje liječnika da provede određene mjere - terapiju. Biološki testament predstavlja dokument kojim potpuno svjesna osoba izražava vlastitu volju o postupcima kojima želi ili ne želi biti izvrgnuta u slučaju teške bolesti ili iznenadne traume, ako ne bude sposobna izraziti vlastitu volju.

U palijativnoj je medicini biološki testament od izuzetne važnosti, što se ogleda u činjenici da će temeljem sastavljenoga i potpisanoga testamenta tim palijativne skrbi točno znati poštivati i postupiti sukladno želji terminalnoga pacijenta, osobito ako se pacijent nalazi u stanju u kojem donošenja odluka nisu moguća. Također, dodatni se problem javlja tada kada članovi obitelji imaju suprotna gledišta o skrbi i provođenju terapije za svojega terminalnoga pacijenta ili pak ako ne poštuju želju svojega člana obitelji. Tada se biološki testament uzima kao konačna odluka, odnosno smjernica.

Palijativna medicina brine i skrbi za život pacijenta do prirodne smrti. Ne usporava niti ne ubrzava smrt. Ne dopušta distanaziju ni eutanaziju. Jedno od najkontroverznijih etičkih pitanja u odnosu na hospicijsku skrb usmjereno je na pojam eutanazije. Jose Maria Simon, bivši predsjednik Međunarodne federacije katoličkih liječničkih društava (FIAMC), izjavio je prije nekoliko godina: »eutanazija je zlo koje ima učinkovito cjepivo, a to je palijativna skrb«. 
Čovjek život treba promicati, a ne uništavati. U našem životu ima nešto što nas same nadilazi, što je veće od nas. Stoga život zahtijeva da ga se istinski i stvarno poštuje. Eutanazija se nameće kao rješenje problema dostojanstvenoga završetka čovjekova života u terminalnoj fazi bolesti, kao rješenje svih njegovih problema, bolova i strahova. Ustvari, eutanazija je lažni humanizam, u kojem nema ničega dostojanstvenoga ni humanoga za ljudsko biće, što je trajno prisutno u povijesti čovječanstva (Pessini, 2004, 225-226).

Palijativna medicina, odnosno skrb pristupa pacijentu na način da mu osigura dostupnost, kontinuitet u pružanju skrbi, stalnu prisutnost uz pacijenta i psihosocijalnu utjehu.

\section{Psihosocijalna podrška terminalnim bolesnicima}

Živimo u društvu u kojem smrt nije dio života. Fraze u kojima se govori o umiranju primjerice "posljednja tabu tema" možda jesu klišeji, no one govore nešto i o načinu razmišljanja suvremenoga društva. Govore nam da se o smrti razmišlja kao o nečem stranom, izvan granica svagdašnjega života i neprirodnom. Unatoč tomu svi znamo da je smrt prirodna.

Kada netko umire, njegova obitelj, rodbina, prijatelji ne mogu više nijekati realnost smrti i ako nisu prije priznali njezino postojanje, slabo su pripremljeni za sučeljavanje s njom. Poricanje smrti stvara jaz između osobe koja umire i društva te se doima kako je umirući isključen iz društvene sredine i prije nego što je napustio život. Upravo je to razlog što je jedna od glavnih misija palijativne medicine psihosocijalna podrška bolesniku, odnosno holistički pristup i stvaranje osjećaja sigurnosti, povjerenja i vjere u tim koji skrbi za terminalnoga bolesnika.

\subsection{Načela psihosocijalne podrške terminalnim bolesnicima}

Palijativna skrb pristupa pacijentu na način da mu osigura dostupnost, kontinuitet u pružanju skrbi, stalnu prisutnost uz pacijenta i psihosocijalnu utjehu. Osigurava bolesnicima: trajnu stručnu skrb, upravljanje simptomima, duhovnu skrb, dostupnost, kontinuitet, ne-napuštanje pacijenta, psihosocijalnu utjehu i žalovanje obitelji kada njezin član premine (Beresford, 1993, 79-81).

Neodvojiv je dio palijativne medicine terminalno bolesnih dostupnost članova interdisciplinarnoga tima. Pacijent s neublaženom boli ne bi trebao dugo čekati na slijed terapije. Saznanje da je netko uvijek dostupan pomaže pacijentu i obitelji (skrbnicima) u nošenju s danim okolnostima, daje utjehu te hrabri pacijenta da neovisno o težini stanja ostane kod kuće.

Osiguravanje stalne stručne skrbi sa sobom povlači ne samo opsežnu skrb, nego podjednaki plan skrbi, kao i podjednaku kvalitetu skrbi. Takva skrb zahtijeva međudjelovanje svih članova tima te traži uključenost obitelji. Vrlo je važno da je skrb svakoga pacijenta popraćena dobrom dokumentacijom kako bi se osigurala trajna evaluacija u sustavu palijativne skrbi. 
Prisutnost uz pacijenata neizostavna je sastavnica palijativne skrbi. Pacijenti često strahuju da će u umiranju biti sami. Umiranje je jedan od naših najvećih, a možda i jedini najveći strah. Još nam je teže suočiti se s tim strahom zbog nedovoljne socijalizacije procesa umiranja, odnosno zbog njegova isključenja iz zajedničkoga iskustva našega društva. Djeca i mlađi punoljetnici zbog medicinskoga napretka sve su manje izloženi smrti i umiranju. Uvjeravanje pacijenata kako oni i njihove obitelji neće biti napušteni tijekom toga nepoznatoga i zastrašujućega iskustva može umanjiti razinu stresa i pomoći u procesu prihvaćanja smrti. Pacijenti, također, strahuju da će se njihovi liječnici prestati skrbiti za njih ako odbiju daljnje kurativne terapije. Nažalost, studije uistinu otkrivaju kako terminalno bolesni ipak primaju manje pažnje u akutnoj bolničkoj okolini. Budući da su zdravstveni djelatnici na svim razinama indoktrinacijom orijentirani ka "liječenju" i nisu dovoljno pripremljeni za rad s umirućima, većina se zaista osjeća vrlo neugodno u prisustvu te skupine pacijenata. Posljedica toga visoka je razina izbjegavanja terminalno oboljelih pacijenata. Takvi pacijenti fizički su izolirani zbog odsutnosti drugih pacijenata, koji s njima ne dijele bolesničku sobu.

Emocionalna izoliranost ogleda se u saznanju da razne osobe ne mogu s njima biti otvorene i iskrene, a logično navedenomu, obeshrabreni su zato što se ne zadovoljavaju njihove temeljne potrebe za udobnosti. Svi su navedeni oblici, na svojevrstan način, oblici napuštanja pacijenta. Bolesnike je vrlo lako utješiti kada im se priopći da će netko biti uz njih kada za to osjete potrebu. Njegovatelji moraju nastojati ostvariti poseban smisao za "prisutnost" kada posjećuju bolesnika, primjerice kupanje bolesnika ili neki drugi postupak kojim na vrlo jednostavan način mogu dokazati pacijentu da se za njega netko skrbi i time mu osigurati osjećaj da nisu sami. Ponekad nisu samo zdravstveni djelatnici krivi za napuštanje. Ponekad to nesvjesno čine i članovi obitelji. Zbog bolesnikove propadajuće energije, tjelesnoga stanja ili izgleda tijela čak će i najbliži biti skloni izostaviti ga iz društvenih događanja, odluka, pa čak i brige za samoga sebe, ne shvaćajući da na taj način napuštaju ili dižu ruke od te osobe. Upravo u tom trenutku interdisciplinarni tim može postupiti tako da predloži način na koji se pacijent može uključiti u razne obiteljske aktivnosti te i nadalje aktivno sudjelovati u obiteljskom životu.

\subsection{Psihosocijalna utjeha bolesnika u završnoj fazi bolesti}

Zasigurno svaki čovjek, odnosno pacijent na kraju svojega života osjeća izvjesnu emocionalnu, društvenu ili duhovnu bol koja izjeda njegovo unutarnje biće i najčešće se izražava bijesom, frustracijom, depresijom ili fizičkom boli.

Emocionalna ili psihološka bol uočena u terminalnih bolesnika gotovo je uvijek rezultat njihovih svjesnih ili podsvjesnih strahova, njihovih osjećaja nemoći i beznađa. Simptomi mogu biti tjeskoba, bijes, nesanica, depresija, razdražljivost ili pritužbe na tjelesnu bol. Najveći je ljudski strah strah od same smrti ili barem strah od nepoznavanja kakva će ona biti, kako će nastupiti i što očekivati. Postoje i strahovi od procesa bolesti, koliku ce bol netko trpjeti, hoće li zadržati zdravi razum, pa čak i strahovi o prosudbi ili kazni u zagrobnom životu. Zasigurno da 
članovi tima ili pak mi liječnici, nećemo ukloniti te strahove, no mnogo možemo učiniti pomaganjem bolesnicima u nošenju s tim strahovima.

Društvene boli koje osjećaju umirući pacijenti najčešće uključuju vrlo temeljne, praktične sadržaje. Na osobnoj razini postoji mnogo zabrinutosti jer se više ne može funkcionirati kao otac ili majka, suprug ili supruga ili član zajednice (Byck, 1996).

Članovi interdisciplinarnoga palijativnoga tima nikada ne smiju očekivati kako će riješiti sve probleme umirućih pacijenata i njihovih obitelji, kao ni to da će svatko umrijeti u savršenom miru ispravljajući sve pogreške. Međutim, članovi interdisciplinarnoga tima moraju biti odgovorno svjesni kako je boravak u hospiciju ili posjet domu bolesnika s ciljem pružanja palijativne skrbi za mnoge posljednja prilika za duševno izlječenje te moraju biti spremni, zajedno s terminalno oboljelim, krenuti putem koji oni sami odaberu (Smith, 2000, 77-95).

Psihosocijalna podrška bolesniku mora biti osigurana od strane interdisciplinarnoga tima kućnih posjeta, odnosno u hospiciju. Bolesnika i obitelj, odnosno skrbnike treba poticati na razgovor, dopustiti im da iskažu svoje osjećaje i strahove. Ukoliko je potrebno, utoliko im treba pokušati pomoći da ciljanim pitanjima sagledaju sve aspekte proživljavanja bolesti. Takve razgovore moraju voditi educirane osobe poput psihologa, psihijatra ili socijalnoga radnika.

Podrška bolesnicima u individualnoj i grupnoj psihosocijalnoj terapiji treba biti osigurana uz interdisciplinaran tim i kroz razne udruge. Takve udruge trebaju imati prostor i vrijeme za razgovore s bolesnicima, članovima njihovih obitelji, odnosno skrbnicima, kao i educirane članove udruge, volontere koji zajedno s medicinskim timom, odnosno interdisciplinarnim timom usko surađuju i brinu o bolesniku.

\subsection{Uobičajene reakcije umirućih pacijenata}

Doktorica Elisabeth Kübler-Ross u svojem je važnom radu u vezi s doživljajima umirućih pacijenata identificirala pet uobičajenih reakcija: nijekanje, ljutnju, cjenkanje, depresiju i prihvaćanje. Okarakterizirala ih je kao "stadije umiranja". Neki stručnjaci raspravljaju o tome kako su navedeni stadiji istiniti i primjenjivi u radu hospicija. Međutim, oni su uistinu najčešće doživljeni i primjenjivi za bilo koju umiruću osobu. Vrlo je važno napomenuti kako bilo koji pojedinac neće iskusiti svih pet stadija, kao i činjenicu da spomenuti stadiji nužno ne predstavljaju određeni slijed doživljaja. Bilo koji od navedenih stadija može koegzistirati jedan s drugim, kao što se može i iznova pojavljivati nebrojeno puta (KöblerRoss, 1975).

Tuga je proces psihološke, društvene i fizičke reakcije na očekivani gubitak. Pritom se očekuju emocionalni osjećaji kao bijes, frustracija, krivnja, usamljenost, koji se prikazuju kao prirodne i popratne reakcije na gubitak. Tuga je popratan osjećaj bilo kojega gubitka (primjerice razvod, gubitak posla, gubitak samopoštovanja) no, općenito, se na smrt gleda kao na konačan i univerzalan gubitak na koji neprestano nailazimo u životu. Očekivana tuga započinje kada pojedinac postane svjestan terminalnoga stanja (budućega gubitka). Vrijeme koje 
preostaje do smrti neizbježno je te se ono može shvatiti kao prilika za razrješavanje sukoba ili završavanje poslova. Osoblje hospicija može pripremiti pacijenta, pacijentovu obitelj i prijatelje na ono što se može očekivati u trenutku smrti, kao i na činjenicu da je u redu pripremati se za život poslije smrti pacijenta.

Gubitak, izvor tuge, može se pojaviti u nekoliko različitih oblika. Pacijent koji ima terminalnu bolest s progresivnim komplikacijama ima potencijal za golem gubitak. Svjesno ili podsvjesno pacijent će tugovati zbog trenutačnih gubitaka, unaprijed očekivanoga budućega gubitka te združenih gubitaka iz prošlosti. Sljedeći popis uključuje neke od mogućih gubitaka koje može iskusiti umirući pacijent kao gubitak kontrole i neovisnosti, gubitak buduće egzistencije, snova i nada za budućnost, gubitak smisla i značajki sebe i svojega identiteta, gubitak drugih važnih ljudi te gubitak obiteljskoga okruženja i vlasništva.

Strahovi su promjenjivi, no postoje tri učestala straha koja se kod većine umirućih pacijenata ponavljaju, to su strah od neolakšane boli, strah od napuštanja ili samoće te strah od nemoći, odnosno bespomoćnosti. Strah od same smrti nalazi se negdje na kraju liste te je usko povezan sa strahom od nepoznatoga. Sva ljudska bića dožive određen strah kad su suočena s nepoznatim, stranim i nepredvidivim događajima. Interdisciplinarni tim palijativne skrbi, osoblje palijativnih odjela i mobilnih palijativnih timova, kao i osoblje hospicija, može pomoći s odgovorima na pitanja tipa: Što će se dogoditi s mojim tijelom nakon smrti? Strahovi koji se tiču sudbine u "budućem životu" trebaju se uputiti svećenstvu. Koji god strahovi mučili pacijente, bilo da na njih imamo ili nemamo odgovor, od velike je važnosti da pacijenti osjete povjerenje i sigurnost, kako bi svoje strahove nama prenijeli i izrazili.

Nada je postojana unatoč svim gubitcima, strahovima i tugama. Prvi izazov koji stoji pred članovima interdisciplinarnoga tima odbacivanje je tradicionalnoga medicinskoga značenja nade, a to je da je nada rezervirana samo za lijek. Radije bi trebali upućivati na činjenicu da postoji više vrsta nada, čak i kada je pacijentu rečeno da se više ništa ne može napraviti u njegovu liječenju. U palijativnoj medicini njeguje se mišljenje da se i tada može puno učiniti i da se može ispuniti nada. Postoji razlika između napuštanja nade i napuštanja određene nade. Pacijenti na umoru vjerojatno će trebati neko vodstvo kako bi prenijeli ili usmjerili svoje nade. Primjerice upitate li pacijenta: "Koji su Vaši ciljevi?", a pacijent odgovori: "Ozdraviti”, tada sljedeće pitanje treba biti: "Koji bi bili Vaši ciljevi ako ne možete ozdraviti?" Nada se može prenijeti od medicinske tehnologije do skrbi visoke razine. Pacijenti imaju nadu kako neće biti ostavljeni, kako će biti oslobođeni boli i kako će drugi nastaviti njihov rad i zagovarati njihove vrijednosti. Nada počiva na sljedećim vrijednostima: prava nada uvijek je temeljena u sadašnjosti; nada se može promijeniti kao što se mijenja i stvarnost; pronalaženje kontrole u prijetećim situacijama pojačava nadu; svaka je čovjekova nada individualna i unikatna; nada slijedi progresivan put razvoja (Brkljačić, 2013, 72-74). 


\section{Zaključak}

Utemeljen i dokazan model skrbi za pacijente u završnoj fazi bolesti je palijativna skrb. Započinje kada su iscrpljene klasične (kurativne) metode liječenja ili kad su znaci širenja maligne bolesti dostigli takav stupanj da ih bolesnik teško podnosi. Prema preporukama Svjetske zdravstvena organizacije zemlje sa srednjim dohotkom, među koje spada i Republika Hrvatska, postepeno trebaju uključiti palijativnu skrb u sve razine zdravstvene zaštite i povećati pokrivenost populacije timovima kućnih posjeta. Iako izložena ratnoj situaciji, prepoznavanje i shvaćanje problematike organiziranja palijativne skrbi Hrvatska je uočila još 1994. godine. U Republici Hrvatskoj zakonski okviri za organizaciju palijativne skrbi stvoreni su još u srpnju 2003. godine stupanjem na snagu novoga Zakona o zdravstvenoj zaštiti. Tim je zakonom palijativna skrb navedena kao jedna od mjera zdravstvene zaštite, a kao djelatnost uvrštena je na primarnu razinu zdravstvene zaštite. Danas, petnaest godina poslije, palijativna i hospicijska skrb implementirane su u zdravstveni sustav Republike Hrvatske.

Palijativna je medicina, odnosno skrb područje gdje postoji obilje etičkih tema. Većina je slična onima koje se pojavljuju u drugim područjima zdravstvene skrbi. Neke se teme, poput onih povezanih s krajem života, osobito pitanje eutanazije, očito jače ističu. Razmišljanja o etičkim načelima uključenima u palijativnu skrb zasnivaju se na prepoznavanju činjenice da neizlječivi i/ili terminalni bolesnik nije biološki ostatak za koji se više ništa ne može učiniti, biće koje treba anesteziju, čiji život ne treba nepotrebno produživati, nego osoba koja je sposobna do samoga svršetka.

U nadi da će Hrvatska u svojoj budućnosti ostvariti kvalitetnu stručnu organizaciju palijativne skrbi, odnosno medicine za svoje terminalno bolesne i nemoćne, ne smijemo zaboraviti na riječi pomoćnoga biskupa zagrebačkoga mons. Valentina Pozaića da je najbolja medicina čovjeku — čovjek (Pozaić, 1990, 157).

\section{Literatura:}

Beauchamp, Tom; Childress, James (1994). Principles of Biomedical Ethics. Oxford: Oxford University.

Beresford, Larry (1993). The Hospice Handbook. Boston: Little, Brown \& Company.

Brkljačić Žagrović, Morana (2010). Palijativna medicina — spoj stručne humane skrbi za terminalno oboljele i medicinske etike. Acta Medica Croatica, 64(4), 235-310.

Brkljačić Žagrović, Morana (2011). Eutanazija — djelo i propust: Naš grijeh, naš grijeh, naš preveliki grijeh!: Autonomija medicinske struke i eutanazija. Zagreb: Hrvatsko katoličko liječničko društvo.

Brkljačić, Morana (2009). Bioetički, zakonodavni i organizacijski preduvjeti primjene suvremenih trendova u hospicijskom pokretu u zdravstvenom sustavu Republike Hrvatske (Doktorski rad). Medicinski fakultet Sveučilišta u Rijeci.

Brkljačić, Morana; Belev, Boris; Šamija, Mirko (2013). Psihosocijalna podrška terminalnim bolesnicima. U: Morana Brkljačić (ur.), Palijativna medicina: Temeljna načela i organizacija: Klinički pristup terminalnom bolesniku: Medicinska etika (str. 69-81). Rijeka: Medicinski fakultet Sveučilišta u Rijeci. 
Brkljačić, Morana; Mavrinac, Marina; Sorta-Bilajac, Iva; Bunjevac, Ivan; Čengić, Tomislav; Golubović, Vesna; Šustić, Alan (2009). An Increasing Older Population Dictates the Need to Organise Palliative Care and Establish Hospices. Collegium Antropologicum, 33(2), 473-480.

Byck, Irena (1996). The Nature of Suffering and the Nature of Opportunity at the End of Life. Clinical Geriatric Medicine, 12(2), 237-252.

Cummings, Ina (1998). The Interdisciplinary Team. U: Doyle David (ur.), Oxford Textbook of Palliative Medicine (str. 19-30). Oxford: Oxford University.

Doyle, Derek; Hanks, GWC; Mac Donald, Neil (1998). Oxford Textbook of Palliative Medicine. Oxford: Oxford University.

Faden, Ruth (1999). Informed Consent. U: Ivan Šegota (ur.), Bioetički svesci: Informed Consent (str. 11). Rijeka: Sveučilište u Rijeci Medicinski fakultet.

Higginson, Irene (2005). End of Life Care: Lessons from Other Nations. Journal of Palliative Medicine, 8(1), 161-173.

Köbler-Ross, Elisabeth (1975). Death: The Final stage of Growth. Englewood Cliffs: Practice Hall.

National Consensus Project for Quality Palliative Care (2004). Clinical Practice Guidelines for Quality Palliative Care. Pittsburg.

Pellegrino, Eduard; Siegler, Mark; Singer, Peter (1990). Teaching Clinical Ethics. The Journal of Clinical Ethics, 1(1), 175-180.

Pessini Leo (2004). Distanazija: Do kada produžavati život? Rijeka: Adamić.

Pessini, Leo (2001). Etička načela palijativne medicine. U: Leo Pessini (ur.), Distanazija: Do kada produžavati život? (str 193-200). São Paulo: Editora do Centro Universitário São Camilo.

Pozaić, Valentin (1990). Pred licem smrti. Zagreb: Filozofsko teološki institut.

Recommendation Rec (2003) 24 of the Committee of Ministers to member states on the organisation of palliative care. Adopted by the Committee of Ministers on 12 November 2003 at the 860th meeting of the Ministers' Deputies (str. 7-10).

Smith, Shirley Ann (2000). Hospice Concepts: A Guide to Palliative Care in Terminal Illness. Illinois: Research Press.

World Health Organisation (2003). WHO Definition of Palliative Care. URL: https://www. who.int/cancer/palliative/definition/en/ (14.06.2019.)

Zurak, Niko (2007). Bioetika i medicinska etika. U: Niko Zurak (ur.), Medicinska etika ( str.197-209). Zagreb: Sveučilište u Zagrebu. 


\section{Medical Ethics in Palliative Care}

\section{Morana Brkljačić**}

\section{Summary:}

Palliative care/medicine is the comprehensive active care of patients with advanced or incurable diseases and also of the members of their families. It is provided by competent interdisciplinary teams with the aim of improving the quality of life of terminally ill patients in accordance with the needs and requirements of both the patient and his/her family. „One who is leaving this earthly life should be given the same attention by the community as the tiny human being just entering this life, "said professor Anica Jušić, MD Ph.D. (1), the founder of palliative medicine in Croatia. We must try to change the mindset in our immediate environment and create a pattern of patient-centered care. In the last twenty years, palliative medicine has taken over the medical profession and has gained in importance all over the world. This is due to the fact that it embodies the concept of care and not just treatment, thus generating general awareness of the importance of care, especially when treatment is no longer possible. Palliative medicine as a branch of medicine which studies and cares for patients with progressive, advanced diseases and a limited life expectancy takes care to optimize the quality of life in the limited remaining time and works toward the acceptance of dying as a natural event. Therefore, health professionals need the interdisciplinary support of psychologists, social workers and pharmacists in order to prevent complications by relieving pain and suffering, by helping to make dying a less painful event worthy of all who participate in it. In accordance with the Code of Medical Ethics and Deontology, one of the most important features of a medical vocation is the desire to help and care for a patient, particularly a seriously ill or diseased person.

Key words: palliative medicine, palliative care, medicine, medical ethics

* Morana Brkljačić, M.D. Ph.D., School of Medicine, University of Zagreb and Croatian Catholic University. Address: Šalata 3, 10000 Zagreb, Croatia and Ilica 242, 10000 Zagreb, Croatia. E-mail:morana_brkljacic@yahoo.co.uk 